\title{
Virologic and clinical characteristics of HBV genotypes/subgenotypes in 487 Chinese pediatric patients with $\mathrm{CHB}$
}

\author{
Yan-Wei Zhong ${ }^{1 \dagger}$, Jin $\mathrm{Li}^{1 \dagger}$, Hong-Bin Song ${ }^{2 \dagger}$, Zhong-Ping Duan ${ }^{3}$, Yi Dong ${ }^{1}$, Xiao-Yan Xing ${ }^{1}$, Xiao-Dong Li ${ }^{1}$, \\ Mei-Lei Gu', Yu-Kun Han', Shi-Shu Zhu ${ }^{1 *}$ and Hong-Fei Zhang ${ }^{*^{*}}$
}

\begin{abstract}
Background: The association of hepatitis B virus (HBV) genotypes/subgenotypes with clinical characteristics is increasingly recognized. However, the virologic and clinical features of HBV genotypes/subgenotypes in pediatric patients remain largely unknown.

Methods: Four hundred and eighty-seven pediatric inpatients with CHB were investigated, including 217 nucleos $(t)$ ide analog-experienced patients. HBV genotypes/subgenotypes and reverse transcriptase (RT) mutations were determined by direct sequencing. The stage of fibrosis and degree of inflammatory activity were evaluated by the Metavir score system.

Results: Among 487 enrolled pediatric patients, HBV genotype C2 and B2 were the most two prevalent (73.7\% and 21.1\%). Comparing with HBV/B2 infected patients, no significant difference was observed in the incidence rate and mutant patterns of lamivudine- or adefovir-resistant mutations in HBV/C2 infected patients $(P>0.05)$. Importantly, we found that the degree of hepatic inflammation degree, fibrosis stage and ALT level were significantly higher in HBV/C2-infected HBeAg positive patients than it was in HBV/B2-infected ones.
\end{abstract}

Conclusions: The pediatric patients with HBV/C2 infection might be more susceptible to develop severe liver pathogenesis.

Keywords: hepatitis B virus, genotypes/subgenoytpes, drug mutation, hepatic inflammation, fibrosis, pediatric patients

\section{Background}

Hepatitis B virus (HBV) infection remains a serious health problem that approximately one third of the world's population has serological evidence of past or present infection with $\mathrm{HBV}$ and 350 million people are chronically infected. As a highly endemic area for HBV infection, it is estimated that 93 million people are infected with HBV in China [1-3]. Approximately 90\% adults with chronic acquired the infection from infancy or in early childhood [4]. HBV as a highly variable virus is at least classified into eight genotypes based on a

\footnotetext{
* Correspondence: 302zss@sina.com; pldc302@126.com

† Contributed equally

'Pediatric Liver Disease Therapy and Research Center, Beijing 302 Hospital, Beijing, China

Full list of author information is available at the end of the article
}

divergence in the entire nucleotide sequence greater than $8 \%$ [3-21]. Each HBV genotype can be further divided into subgenotypes on the basis of a greater than $4 \%$ but less than $8 \%$ divergence in the complete nucleotide sequence $[3,12,14,22]$. As of now, $\mathrm{HBV} / \mathrm{B}, \mathrm{HBV} / \mathrm{C}$, and $\mathrm{HBV} / \mathrm{D}$ have been individually classified into five subgenotypes each, HBV/B1 to B5 [3,23], HBV/C1 to C5 $[3,24,25]$ and HBV/D1 to D5 [3,24]. Some investigations indicated that $\mathrm{C} 1$ and $\mathrm{C} 2$ were predominant subgenotypes in the southern and northern parts of China, respectively [14,26-29]. Although the prevalence and clinical features of HBV genotypes/subgenotypes have been investigated in adult patients [3,9,30], However, the virologic and clinical features of HBV genotypes/ subgenotypes in Chinese pediatric patients remain largely unknown.

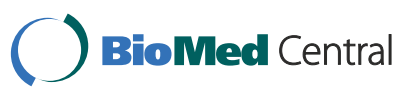

() 2011 Zhong et al; licensee BioMed Central Ltd. This is an Open Access article distributed under the terms of the Creative Commons Attribution License (http://creativecommons.org/licenses/by/2.0), which permits unrestricted use, distribution, and reproduction in any medium, provided the original work is properly cited. 


\section{Methods \\ Patients}

Four hundred and eighty-seven pediatric inpatients with CHB who visited Beijing 302 Hospital from September 2007 to September 2010 were enrolled in the study. They were mainly from different regions of Northern China, All patients were anti-HCV and anti-HIV negative (375 males, 112 females, mean age $12 \pm 5.7$ years; range 3-18 years). The diagnostic and treatment criteria were based on "European Association for the Study of the Liver", 2009, EASL clinical practice guidelines: management of chronic hepatitis B [1]. For all patients, there was no evidence of $\mathrm{HCC}$, concomitant of $\mathrm{HCV}$, HDV, and HIV infection, metastatic or autoimmune liver disease. Two hundred and seventeen patients were exposed to nucleos(t)ide analog(s). The inclusion criteria were: all patients who were serum HBsAg positive for at least 6 months, but there was no evidence for HCC, or concomitant of HCV, HDV, HIV infection and autoimmune liver disease. The excluded criteria were: patients with acute hepatitis A, B, HCV, HDV, or HIV co-infection, and drug induced acute hepatitis, existence of renal failure, hepatic decompensation or psychiatric disorders, and central nervous system disease such as epilepsy, had received bone marrow or organ transplants, or had received immunosuppressive, nephrotoxic, or hepatotoxic medications within 2 months of enrollment. The study protocol was approved by the Beijing 302 Hospital Research Ethnics Committee, and written informed consents for therapy and study were obtained from each patient's parents.

\section{Detection of Serological Markers and Analysis of HBV Sequence}

Serological markers and quantitation of HBV DNA, serum alanine aminotransferase (ALT), aspartate aminotransferase (AST), total bilirubin (TBIL), and other biochemical parameters were measured by standard procedures. $\mathrm{HBeAg} / \mathrm{anti}-\mathrm{HBe}, \mathrm{HBsAg} / \mathrm{anti}-\mathrm{HBs}$ and anti-HBc were detected by enzyme-linked immunosorbent (Kewei Diagnostic Ltd., Beijing, China) or chemiluminescent assay (Abbott Laboratories, North Chicago,
IL, USA). HBV DNA level was determined by a realtime polymerase chain reaction (PCR) kit (Fosun Pharmaceutical Co., Shanghai, China) with a lower limit of detection of 500 copies $/ \mathrm{mL}$ (about $100 \mathrm{IU} / \mathrm{mL}$ ). HBV genotype/subgenotype assignment was based on the analysis of the $1225 \mathrm{bp}$-long S/Pol-gene sequence (nt 54-1278) as described previously [31]. The sense and antisense primers designed respectively for the firstround PCR were desigened respectively followed [3]. Direct sequencing was performed using an ABI 3730xl DNA Analyzer (Applied Biosystems, Foster City, CA). Phylogenetic and molecular analyses were performed in MEGA version 4.0 [32]. Phylogenetic trees were constructed using neighbor-joining (NJ) analysis with bootstrap test confirmation performed on 1000 resampling standard reference sequences were acquired from the online Hepatitis Virus Database which can be found at: http://www.ncbi.nlm.nih.gov/projects/genotyping/formpage.cgi.

\section{Analysis of Genotypic/Subgenotypic Drug Mutations}

Drug-resistance-associated mutations in the RT region of the HBV genome were analyzed as previously described [31]. Substitutions at positions rt80, rt173, rt180, rt181, rt204, rt214, rt229, rt233 and rt236 were taken as resistance-associated mutations for analysis.

\section{Analysis of Histopathological}

The stage of fibrosis and the degree of inflammatory activity were evaluated by the Metavir score system [5], which classifies fibrosis into five stages: F0-no fibrosis, F1-portal fibrosis without septa, F2-portal fibrosis with few septa, F3-portal fibrosis with numerous septa, without cirrhosis, F4-cirrhosis. The degrees of inflammatory activity were divided into: A0-lack of histological activity, A1-mild histological activity, A2-moderate histological activity, A3-severe histological activity.

\section{Statistical Analysis}

Measurement data were expressed as means \pm standard deviations. Differences in Measurement data were examined by Student's $t$ test and analysis of variance; the numeration

Table 1 Characteristics and HBV genotypes/subgenotypes frequencies among 487 pediatric patients

\begin{tabular}{lccccccccc}
\hline HBV subgenotype & B1 & B2 & B3 & B4 & C1 & C2 & C3 & C4 & D \\
\hline Case number & 1 & 103 & 1 & 3 & 7 & 359 & 5 & 2 & 6 \\
Percentage (\%) & 0.2 & 21.1 & 0.2 & 0.6 & 1.4 & 73.7 & 1.03 & 0.41 & 1.23 \\
Age (years) & 13 & $15 \pm 3$ & 17 & $14 \pm 3$ & $16 \pm 1$ & $14 \pm 3$ & $14 \pm 3$ & $16 \pm 1$ & $14 \pm 3$ \\
Male/female & $1 / 0$ & $81 / 22$ & $1 / 0$ & $3 / 0$ & $6 / 1$ & $275 / 84$ & $2 / 3$ & $2 / 0$ & $4 / 2$ \\
HBV DNA (log IU/mL) & 4.90 & $5.33 \pm 1.63$ & 5.35 & $5.56 \pm 1.51$ & $4.66 \pm 1.68$ & $5.50 \pm 1.63$ & $5.59 \pm 0.91$ & $4.98 \pm 1.16$ & $5.55 \pm 2.09$ \\
TBIL ( $\mu \mathrm{mol} / \mathrm{L})$ & 10.9 & $11.48 \pm 5.78$ & 21.6 & $11.9 \pm 6.65$ & $9.54 \pm 2.28$ & $14.28 \pm 34.93$ & $7.9 \pm 2.49$ & $5.4 \pm 2.8$ & $10 \pm 2.68$ \\
$\mathrm{ALT}(\mathrm{U} / \mathrm{L})$ & 10 & $70.48 \pm 85.5$ & 1002 & $179 \pm 4.24$ & $18 \pm 8.28$ & $116.8 \pm 224.7$ & $192.5 \pm 166.0$ & $29 \pm 5.6$ & $31.5 \pm 2.12$ \\
$\mathrm{HBeAg}+(\mathrm{n})$ & 1 & 86 & 0 & 1 & 4 & 291 & 5 & 1 & 5 \\
\hline
\end{tabular}




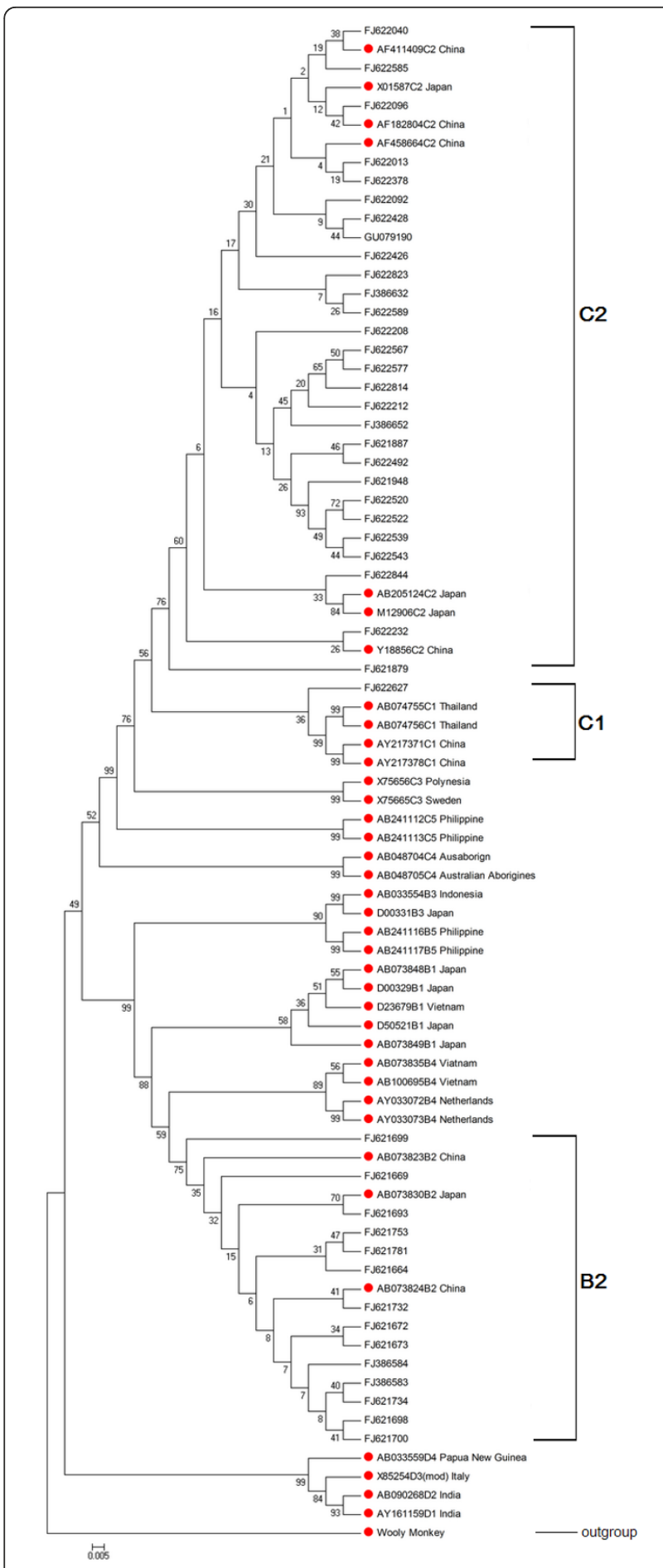

Figure 1 Phylogenetic tree based on 43 representative HBV genetic sequences analyzed with GenBank accession numbers Standard reference sequences are marked by circles.

data were analyzed by chi-square test. Logistic regression was used to evaluate $P$ values in multivariate analysis. Statistical analysis was carried out with SPSS 16.0 software. A Pvalue of $<0.05$ was considered statistically significant.

\section{Results}

The main characteristics and the frequencies of the viral subgenotypes in the 487 pediatric patients are shown in Table 1. Among 487 enrolled pediatric patients, eighty-one percent of the patients were $\mathrm{HBeAg}$ positive $(76.4 \%$ genotypes $\mathrm{C} ; 22.3 \% \mathrm{~B} ; 1.3 \% \mathrm{D})$, about $60 \%$ of them had alanine aminotransferase of up to 1.5 times the normal level (upper limit $40 \mathrm{U} / \mathrm{L})$. As shown in Table 1, the subgenotype distribution was as follows: 1 (0.2\%) for B1, 103 (21.1\%) for B2 (for example: FJ621698, FJ621673, FJ621664, FJ621732, FJ621700, FJ621781, FJ621753, FJ621734, FJ621672, FJ621669, etc.), and 1 (0.2\%) for B3, 3 (0.6\%) for B4 (for example: FJ621693 and FJ621699), 7 (1.4\%) for C1 (for example: FJ621879, FJ622823, etc.), 359 (73.7\%) for C2 (for example: FJ622585, FJ386652, FJ622577, FJ621948, FJ386584, FJ622844, FJ386583, FJ622013, FJ386632, FJ622539, FJ622092, etc.), 5 (1.0\%) for C3 (for example: FJ622096, FJ622627, etc.), 2 (0.4\%) for C4, and 6 (1.2\%) for D. No other genotypes (A, E, F, G, or H) were detected in enrolled samples enrolled for this study. Thus, HBV/C2 was the most predominant subgenotype among enrolled patients, followed by HBV/B2. A phylogenetic tree based on the 43 representative HBV genetic sequences, analyzed with GenBank accession numbers is presented in Figure 1. No obvious differences were observed in age, gender, serum HBV DNA level, TBIL, and HBeAg positive rate between $\mathrm{HBV} / \mathrm{C} 2$ and $\mathrm{HBV} / \mathrm{B} 2$ infected patients.

Among 217 nucleos(t)ide analog-experienced patients, a comparison of drug-resistant mutational patterns between $\mathrm{HBV} / \mathrm{B} 2$ and $\mathrm{HBV} / \mathrm{C} 2$ showed that the incidence rate and mutant patterns of LAM-resistant or ADV-resistant mutations were similar between the two subsets, and no significant difference was found $(P>$ 0.05) (Tables 2 and 3).

Among the 487 pediatric inpatients with $\mathrm{CHB}, 187$ HBeAg positive patients who were submitted to liver biopsy, the mean degree of inflammation was determined for $\mathrm{HBV} / \mathrm{C} 2$ and $\mathrm{HBV} / \mathrm{B} 2$ patients $(2.1 \pm 0.4$ vs $1.6 \pm 0.4)$, and the mean stage of fibrosis was determined for $\mathrm{HBV} /$ $\mathrm{C} 2$ and $\mathrm{HBV} / \mathrm{B} 2$ patients $(1.9 \pm 0.89$ vs $1.3 \pm 0.6)$. The mean degree of inflammation, the stage of fibrosis and the ALT level in $\mathrm{HBV} / \mathrm{C} 2$ patients were significantly higher than in HBV/B2 patients $(P<0.05)$ (Table 4$)$. The sample size of $\mathrm{HBeAg}$-negative patients was too small to be analyzed. Factors (such as sex, age, routes of infection, therapeutic effects) that can be affect the degree of inflammation, the stage of fibrosis and ALT level of $\mathrm{HBV} / \mathrm{B} 2, \mathrm{C} 2$ patients have been analyzed by multiple logistic regression, and the results indicated that there is no statistically significant difference between them.

\section{Discussion and conclusions}

HBV genotypes/subgenotypes have been reported to have various effects on the clinical course of patients 
Table 2 LAM-assosiated resistant mutantion in subgenotypes B2 and C2

\begin{tabular}{lcccccccc}
\hline Subgenotype & Total & M204I & M204V & M204I/ & L80I & V173L & L180M & M204I+CM \\
\hline B2 $(n=30)$ & $17(56.7)$ & $2(11.7)$ & 0 & 0 & $1(5.8)$ & 0 & 0 & $14(82.3)$ \\
C2 $(\mathrm{n}=76)$ & $34(44.7)$ & $10(29.4)$ & 0 & 0 & 0 & $1(2.9)$ & 0 & $23(67.6)$ \\
$P$ & 0.27 & 0.29 & $\mathrm{~N}$ & $\mathrm{~N}$ & 0.72 & 1 & $\mathrm{~N}$ & 0.57 \\
\hline
\end{tabular}

Table 3 ADV-assosiated resistant mutantion in subgenotypes B2 and C2

\begin{tabular}{lcccccccc}
\hline Subgenotype & Total & V84M & A181T/V & A181V+N236T & N236T & I233 & V214A & L229V \\
\hline B2 $(\mathrm{n}=30)$ & $5(16.6)$ & 0 & $1(20.0)$ & $1(20.0)$ & 0 & 0 & 0 & $3(60.0)$ \\
C2 $(\mathrm{n}=81)$ & $19(23.4)$ & 0 & $4(21.0)$ & 0 & 0 & $4(21.0)$ & $4(21.0)$ & $7(36.8)$ \\
$P$ & 0.44 & $\mathrm{~N}$ & 1 & 0.208 & $\mathrm{~N}$ & 0.544 & 0.544 & 0.615 \\
\hline
\end{tabular}

with HBV related liver diseases [2,4,7,9,13,18,21,33-37]. However, most of previous study data were from adult patients, studies on the pediatric patients were rare, especially in China. To our knowledge, there were seldom study to analyze the relationship among the genotypes/subgenotypes and NA resistance as well as the disease progression in pediatric patients. The relationship between HBV genotypes/subgenotypes and NA resistance, as well as the disease progression in pediatric patients, were analyzed in this study.

The data obtained from adult patients indicate that HBV genotypes/subgenotypes have distinct geographic distributions patterns $[2,8,15,16,18,20-22,27,37-42]$. Genotypes $\mathrm{B}$ and $\mathrm{C}$ are the most common HBV genotypes in China [14,28]. Our results indicate that among the 487 pediatric patients with $\mathrm{CHB}, \mathrm{HBV}$ genotype $\mathrm{C}$ was the most prevalent (76.4\%), while genotypes B and D were found in $22.3 \%$ and $1.3 \%$, respectively. Genotypes E, F, G and $\mathrm{H}$ were not found. About $60 \%$ of these patients had ALT up to 1.5 times the normal level. The prevalence and the geographical pattern of the genotypes/subgenotypes of our pediatric patients were in consistent with previous reports in adults $[3,41]$. In addition, there were no significant genotypes/subgenotypes differences were found in age, gender, in serum HBV DNA levels, TBIL, and in $\mathrm{HBeAg}$-positive rate among patients infected with $\mathrm{HBV} / \mathrm{B} 2$ and $\mathrm{HBV} / \mathrm{C} 2$.

NA are commonly used in clinical treatment for suppressing viral replication to halt the progression of liver diseases caused by chronic HBV infection $[3,4,42,43]$. The clinical implications of occurring HBV subgenotypes are far from well understood, especially in pediatric patients. Previous studies about adults exhibited that $\mathrm{HBV} / \mathrm{B} 2$ differ from to $\mathrm{HBV} / \mathrm{C} 2$ in LAM- or from ADV-resistant mutational patterns [3], suggesting that HBV subgenotypes might have an impact on drug resistance. However, when we compared the association of LAM- or ADV- resistance mutational rates with $\mathrm{HBV} /$ $\mathrm{B} 2$ and $\mathrm{HBV} / \mathrm{C} 2$ in pediatric patients respectively, we did not find significant differences between the two groups. The difference between adults and pediatric patients in this respect may be explained by following reasons: (1) adult patients possibly have a longer time of infection and therapy than do pediatric patients, which may increase the incidence rate and extent of NArelated resistance mutations. (2) The different host's immune response to the virus between the adults and pediatric patients determines the extent of NA resistant rates and patterns [2]. Additional large population-based studies are needed to confirm this inference.

In this study, we also analyzed the relationship between subgenotypes and disease progression. We found that HBV/B2 patients had a significantly lower incidence of inflammation and fibrosis than HBV/C2 in pediatric patients. Moreover, in our previous studies, the double mutation in BCP (T1762/A1764) was obviously more frequent in genotype $\mathrm{C}(26 \%)$ than that in genotype B patients $(9.8 \%, P<0.05)$. However, there was no significant difference in preC (A1896) between genotype $\mathrm{B}(3.7 \%)$ and genotype $\mathrm{C}(2.8 \%, P>0.05)$. According to the relevant literature, there are some correlations between the mutation in $\mathrm{HBV} \mathrm{BCP}$ region and disease progression [44].

In conclusion, $\mathrm{HBV} / \mathrm{C} 2$ is the most predominant subgenotype in pediatric patients of Northern China. Pediatric patients with subgenotype $\mathrm{C} 2$ virus might be more

Table 4 The association of clinic character with HBV subgenotypes in HBeAg positive patients

\begin{tabular}{lcccc}
\hline Subgenotype & Inflammation degree & Fibrosis stage & DNA load $(\log$ IU/mL) & ALT (U/L) \\
\hline B2 $(n=31)$ & $1.6 \pm 0.4$ & $1.3 \pm 0.6$ & $7.7 \pm 7.8$ & $84 \pm 87$ \\
C2 $(n=90)$ & $2.1 \pm 0.4$ & $1.9 \pm 0.8$ & $7.8 \pm 8.2$ & $153 \pm 194$ \\
$P$ & 0.002 & 0.039 & 0.545 & 0.047 \\
\hline
\end{tabular}


susceptible to disease progression. Nucleos(t)ide analog therapeutic decisions might not be based primarily on genotypes/subgenotypes in pediatric patients at present. Our results provide new insights in features of HBV subgenotypes which may have important clinical implications for the management of HBV infections in pediatric patients.

\section{Acknowledgements}

This study was supported by the Capital Medical Developing Foundation of Beijing (No. 2009-3057), Wujieping Medical Foundation (No. LDWMF-SY2011A004) and the Military Subject of the Twelfth Five-year Plan for Science \& Technology Research of China (2011-2013). The funders had no role in study design, data collection and analysis, decision to publish, or preparation of the manuscript.

\section{Author details}

${ }^{1}$ Pediatric Liver Disease Therapy and Research Center, Beijing 302 Hospital, Beijing, China. ${ }^{2}$ Institute of Disease Control and Prevention, Academy of Military Medical Sciences, Beijing, China. ${ }^{3}$ Beijing You'an Hospital, Capital Medical University, Beijing, China.

\section{Authors' contributions}

YWZ, HFZ, SSZ designed the study. YWZ, YD, XYX, XDL, MLG, YKH performed experiments. YWZ, JL, HBS, ZPD analyzed data and discussed results. YWZ, SSZ, HFZ wrote manuscript. All authors read and approved the final manuscript.

\section{Competing interests}

The authors declare that they have no competing interests.

Received: 11 February 2011 Accepted: 30 September 2011 Published: 30 September 2011

\section{References}

1. European association for the study of the liver: EASL clinical practice guidelines: management of chronic hepatitis B. J Hepatol 2009, 50:227-242.

2. McMahon BJ: The influence of hepatitis B virus genotype and subgenotype on the natural history of chronic hepatitis B. Hepatol Int 2009, 3(2):334-342.

3. Li X, Wang L, Zhong Y, Wong WW, Xu Z, Liu Y, Li Q, Xin S, Zhao J, Xu D: Hepatitis $B$ virus (HBV) subgenotypes $C 2$ and $B 2$ differ in lamivudineand adefovir-resistance-associated mutational patterns in HBV-infected Chinese patients. J Clin Microbiol 2010, 48(12):4363-4369.

4. Jonas MM, Block JM, Haber BA, Karpen SJ, London WT, Murray KF, Narkewicz MR, Rosenthal P, Schwarz KB, McMahon BJ: Treatment of children with chronic hepatitis B virus infection in the United States: patient selection and therapeutic options. Hepatology 2010, 52(6):2192-2205

5. Tonetto PA, Gonçales NS, Fais VC, Vigani AG, Gonçales ES, Feltrin A, Gonçales FL Jr: Hepatitis B virus: molecular genotypes and $\mathrm{HBeAg}$ serological status among HBV-infected patients in the southeast of Brazil. BMC Infect Dis 2009, 9:149.

6. Ozasa A, Tanaka Y, Orito E, Sugiyama M, Kang JH, Hige S, Kuramitsu T, Suzuki K, Tanaka E, Okada S, Tokita H, Asahina Y, Inoue K, Kakumu S, Okanoue T, Murawaki Y, Hino K, Onji M, Yatsuhashi H, Sakugawa H, Miyakawa Y, Ueda R, Mizokami M: Influence of genotypes and precore mutations on fulminant or chronic outcome of acute hepatitis B virus infection. Hepatology 2006, 44(2):326-334.

7. Akuta N, Kumada H: Influence of hepatitis B virus genotypes on the response to antiviral therapies. J Antimicrob Chemoth 2005, 55(2):139-142.

8. Sugauchi F, Orito E, Ichida T, Kato H, Sakugawa H, Kakumu S, Ishida T, Chutaputti A, Lai CL, Gish RG, Ueda R, Miyakawa Y, Mizokami M: Epidemiologic and virologic characteristics of hepatitis B virus genotype B having the recombination with genotype C. Gastroenterology 2003, 124(4):925-932.
9. Mahtab MA, Rahman S, Khan M, Karim F: Hepatitis B virus genotypes: an overview. HBPD Int 2008, 7(5):457-464.

10. Nurainy N, Muljono DH, Sudoyo H, Marzuki S: Genetic study of hepatitis B virus in Indonesia reveals a new subgenotype of genotype $B$ in east Nusa Tenggara. Arch Virol 2008, 153(6):1057-1065.

11. Akman SA, Kose $S$, Halicioglu O: Lamivudine and adefovir resistance in children and young adults with chronic hepatitis B. Int I Infect Dis 2010, 14(3):e236-239.

12. Chan HL, Tsui SK, Tse CH, Ng EY, Au TC, Yuen L, Bartholomeusz A, Leung KS, Lee KH, Locarnini S, Sung JJ: Epidemiological and virological characteristics of 2 subgroups of hepatitis B virus genotype C.J Infect Dis 2005, 191(12):2022-2032.

13. Olinger CM, Lazouskaya NV, Eremin VF, Muller CP: Multiple genotypes and subtypes of hepatitis B and C viruses in Belarus: similarities with Russia and western European influences. Clin Microbiol Infect 2008, 14(6):575-581.

14. Wang Z, Tanaka Y, Huang Y, Kurbanov F, Chen J, Zeng G, Zhou B, Mizokami M, Hou J: Clinical and virological characteristics of hepatitis B virus subgenotypes $\mathrm{Ba}, \mathrm{C1}$, and C2 in China. J Clin Microbiol 2007, 45(5):1491-1496.

15. Wang Z, Liu Z, Zeng G, Wen S, Qi Y, Ma S, Naoumov NV, Hou J: A new intertype recombinant between genotypes $C$ and $D$ of hepatitis $B$ virus identified in China. J Gen Virol 2005, 86(Pt 4):985-990.

16. Banerjee A, Kurbanov F, Datta S, Chandra PK, Tanaka Y, Mizokami M, Chakravarty R: Phylogenetic relatedness and genetic diversity of hepatitis B virus isolates in Eastern India. J Med Virol 2006, 78(9):1164-1174.

17. Myers R, Clark C, Khan A, Kellam P, Tedder R: Genotyping Hepatitis B virus from whole- and sub-genomic fragments using position-specific scoring matrices in HBV STAR. J Gen Virol 2006, 87(Pt 6):1459-1464.

18. Zeng G, Wang Z, Wen S, Jiang J, Wang L, Cheng J, Tan D, Xiao F, Ma S, Li W, Luo K, Naoumov NV, Hou J: Geographic distribution, virologic and clinical characteristics of hepatitis B virus genotypes in China. J Viral Hepaitist 2005, 12(6):609-617.

19. Khan A, Kurbanov F, Tanaka Y, Elkady A, Sugiyama M, Dustov A, Mizokami M: Epidemiological and clinical evaluation of hepatitis B, hepatitis C, and delta hepatitis viruses in Tajikistan. J Med Virol 2008, 80(2):268-276

20. Yano Y, Truong BX, Seo Y, Kato H, Miki A, Tanaka Y, Mizokami M, Kagawa A, Miyazaki H, Kasuga M, Azuma T, Hayashi Y: Japanese case of hepatitis B virus genotypes C/D hybrid. Hepatol Res 2007, 37(12):1095-1099.

21. Bartholomeusz A, Schaefer $S$ : Hepatitis B virus genotypes: comparison of genotyping methods. Rev Med Virol 2004, 14(1):3-16

22. Norder $H$, Couroucé AM, Coursaget P, Echevarria JM, Lee SD, Mushahwar IK, Robertson BH, Locarnini S, Magnius LO: Genetic diversity of hepatitis B virus strains derived worldwide: genotypes, subgenotypes, and $\mathrm{HBsAg}$ subtypes. Intervirology 2004, 47(6):289-309.

23. Sakamoto T, Tanaka Y, Simonetti J, Osiowy C, Borresen ML, Koch A, Kurbanov F, Sugiyama M, Minuk GY, McMahon BJ, Joh T, Mizokami M: Classification of hepatitis B virus genotype B into 2 major types based on characterization of a novel subgenotype in Arctic indigenous populations. J Infect Dis 2007, 196(10):1487-1492.

24. Lusida MI, Nugrahaputra VE, Soetjipto Handajani R, Nagano-Fujii M, Sasayama M, Utsumi T, Hotta H: Novel subgenotypes of hepatitis B virus genotypes C and D in Papua, Indonesia. J Clin Microbiol 2008, 46(7):2160-2166.

25. Sakamoto T, Tanaka Y, Orito E, Co J, Clavio J, Sugauchi F, Ito K, Ozasa A, Quino A, Ueda R, Sollano J, Mizokami M: Novel subtypes (subgenotypes) of hepatitis $B$ virus genotypes $B$ and $C$ among chronic liver disease patients in the Philippines. J Gen Virol 2006, 87(7):1873-1882.

26. Yuan J, Zhou B, Tanaka Y, Kurbanov F, Orito E, Gong Z, Xu L, Lu J, Jiang X, Lai W, Mizokami M: Hepatitis B virus (HBV) genotypes/subgenotypes in China: mutations in core promoter and precore/core and their clinical implications. J Clin Virol 2007, 39(2):87-93.

27. Wang Z, Hou J, Zeng G, Wen S, Tanaka Y, Cheng J, Kurbanov F, Wang L, Jiang J, Naoumov NV, Mizokami M, Qi Y: Distribution and characteristics of hepatitis B virus genotype $C$ subgenotypes in China. J Viral Hepaititis 2007, 14(6):426-434.

28. Wang $Z$, Huang $Y$, Wen $S$, Zhou B, Hou J: Hepatitis B virus genotypes and subgenotypes in China. Hepatol Res 2007, 37(s1):S36-41.

29. Zhang HW, Yin JH, Li YT, Li CZ, Ren H, Gu CY, Wu HY, Liang XS, Zhang P, Zhao JF, Tan XJ, Lu W, Schaefer S, Cao GW: Risk factors for acute hepatitis 
B and its progression to chronic hepatitis in Shanghai, China. Gut 2008, 57(12):1713-1720.

30. Orito E, Fujiwara K, Tanaka Y, Yuen MF, Lai CL, Kato T, Sugauchi F,

Kusakabe A, Sata M, Okanoue T, Nitsuma H, Sakugawa H, Hasegawa I,

Mizokami M: A case-control study of response to lamivudine therapy for 2 years in Japanese and Chinese patients chronically infected with hepatitis B virus of genotypes Bj, Ba and C. Hepatol Res 2006, 35(2):127-134.

31. Liu Y, Zhong Y, Zou Z, Xu Z, Li B, Ren X, Bai S, Wang L, Li X, Dai J, Wang Y, Mao $P, X u$ D: Features and clinical implications of hepatitis $B$ virus genotypes and mutations in basal core promoter/precore region in 507 Chinese patients with acute and chronic hepatitis B. J Clin Virol 2010, 47(3):243-247.

32. Koichiro T, Joel D, Masatoshi N, Sudhir K: MEGA4: Molecular Evolutionary Genetics Analysis (MEGA) Software Version 4.0. Mol Biol Evol 2007, 24(8):1596-1599.

33. Huy $\Pi$, Abe $K$ : Molecular epidemiology of hepatitis $B$ and $C$ virus infections in Asia. Pediatr Int 2004, 46(2):223-230.

34. Utama A, Purwantomo S, Siburian MD, Dhenni R, Gani RA, Hasan I, Sanityoso A, Miskad UA, Akil F, Yusuf I, Achwan WA, Soemohardjo S, Lelosutan SA, Martamala R, Lukito B, Budihusodo U, Lesmana LA, Sulaiman A, Tai S: Hepatitis B virus subgenotypes and basal core promoter mutations in Indonesia. World J Gastroenterol 2009, 15(32):4028-4036.

35. Huy TT, Ushijima H, Quang VX, Win KM, Luengrojanakul P, Kikuchi K, Sata T, Abe K: Genotype C of hepatitis B virus can be classified into at least two subgroups. J Gen Virol 2004, 85(Pt 2):283-292.

36. Hussain M, Chu CJ, Sablon E, Lok AS: Rapid and sensitive assays for determination of hepatitis $B$ virus (HBV) genotypes and detection of HBV precore and core promoter variants. J Clin Microbiol 2003, 41(8):3699-3705.

37. Zhu L, Tse CH, Wong WW, Chim AM, Leung KS, Chan HL: A complete genomic analysis of hepatitis $B$ virus genotypes and mutations in HBeAg-negative chronic hepatitis B in China. J Viral Hepatitis 2008, 15(6):449-458.

38. Hiroshi Yotsuyanagi, Kunihiko Hino, Eiichi Tomita, Joji Toyoda, Kiyomi Yasuda, Shiro lino: Precore and core promoter mutations, hepatitis B virus DNA levels and progressive liver injury in chronic hepatitis B. $J$ Hepatol 2002, 37(3):355-363.

39. Suwannakarn K, Tangkijvanich P, Theamboonlers A, Abe K, Poovorawan Y: A novel recombinant of Hepatitis $B$ virus genotypes $G$ and $C$ isolated from a Thai patient with hepatocellular carcinoma. J Gen Virol 2005, 86(Pt 11):3027-3030

40. Tallo T, Tefanova V, Priimägi L, Schmidt J, Katargina O, Michailov M, Mukomolov S, Magnius L, Norder H: D2: major subgenotype of hepatitis B virus in Russia and the Baltic region. J Gen Virol 2008, 89(Pt 8):1829-1839.

41. Schaefer $\mathrm{S}$ : Hepatitis B virus taxonomy and hepatitis B virus genotypes. World I Gastroenterol 2007, 13(1):14-21.

42. Zeng G, Wang Z, Wen S, Jiang J, Wang L, Cheng J, Tan D, Xiao F, Ma S, Li W, Luo K, Naoumov NV, Hou J: Geographic distribution, virologic and clinical characteristics of hepatitis B virus genotypes in China. J Viral Hepatitis 2005, 12(6):609-617.

43. Zoulim F, Locarnini S: Hepatitis B virus resistance to nucleos(t)ide analogues. Gastroenterology 2009, 137(5):1593-1608.

44. Hiroshi Y, Kunihiko H, Eiichi T, Joji T, Kiyomi Y, Shiro I: Precore and core promoter mutations, hepatitis $B$ virus DNA levels and progressive liver injury in chronic hepatitis B. J Hepatol 2002, 37(3):355-363.

\section{Pre-publication history}

The pre-publication history for this paper can be accessed here: http://www.biomedcentral.com/1471-2334/11/262/prepub

doi:10.1186/1471-2334-11-262

Cite this article as: Zhong et al: Virologic and clinical characteristics of HBV genotypes/subgenotypes in 487 Chinese pediatric patients with CHB. BMC Infectious Diseases 2011 11:262. 